
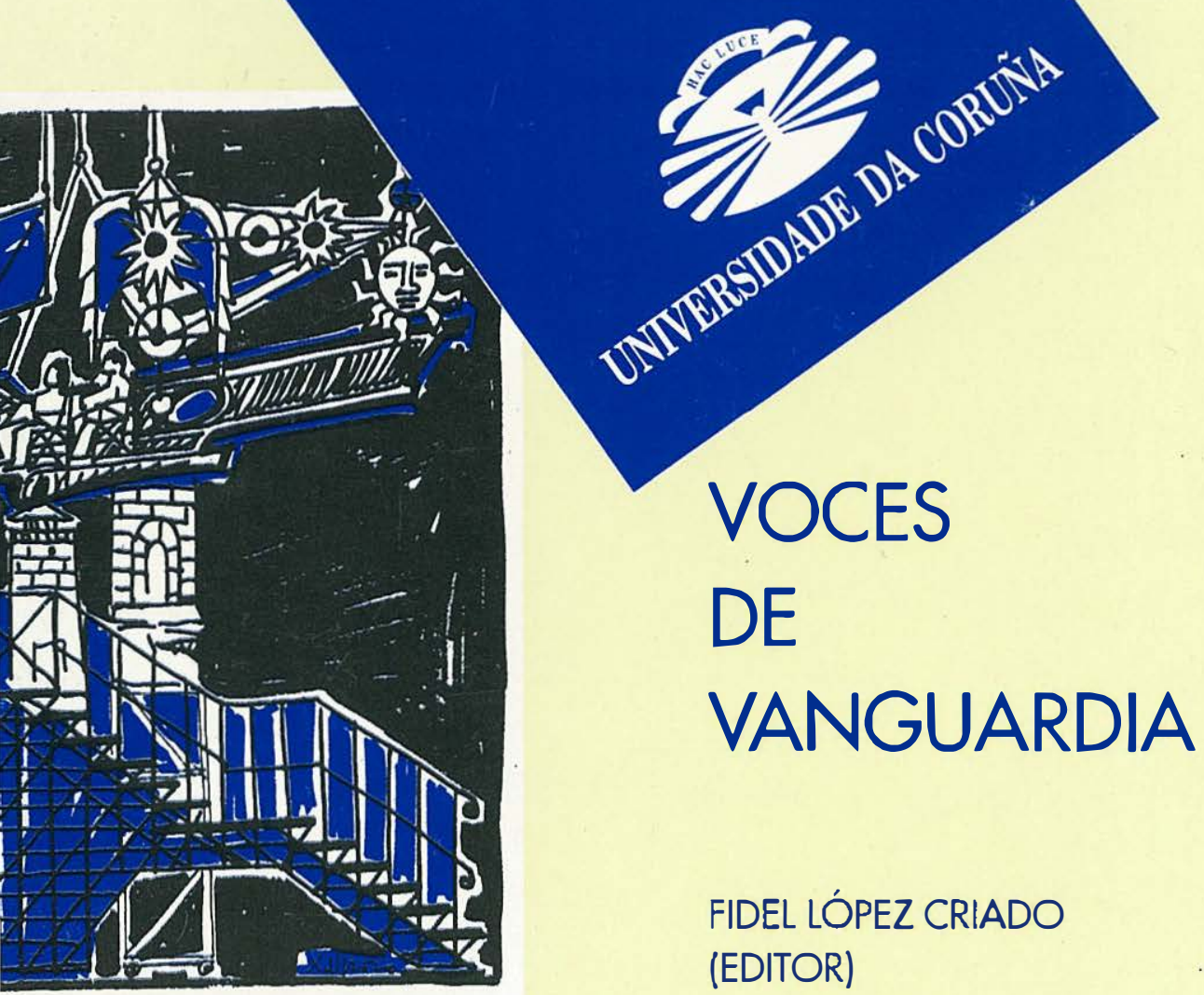

FIDEL LÓPEZ CRIADO (EDITOR)

COLECCION: CURSOS, CONGRESOS E SIMPOSIOS 


\section{VOCES DE VANGUARDIA}

Fidel López Criado (Editor)

Actas del Ciclo de Conferencias "El nuevo siglo: el hombre y el arte en las vanguardias", celebrado en la Universidad de A Coruña, en octubre de 1994, bajo la dirección del profesor Fidel López Criado. 
DOI: https://doi.org/10.17979/spudc. 9788497497725

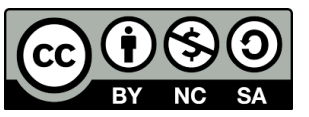

Esta obra se publica en su formato electrónico bajo una licencia

Creative Commons Atribución-NoComercial-CompartirIgual 4.0 Internacional (CC BY-NC-SA 4.0)

COLECCIÓN: CURSOS,

CONGRESOS E SIMPOSIOS $\mathbf{1 8}$

\section{VOCES DE VANGUARDIA}

EDICIÓN:

UNIVERSIDADE DA CORUÑA

SERVICIO DE PUBLICACIÓNS

(C) DE ESTA EDICIÓN

\section{UNIVERSIDADE DA CORUÑA}

Imprime: ImpañA MENoo, s.L.

Depósito Legal: C-996/1995

Depósito Legal: C-560/2020 (electrónico)

I.S.B.N.: 84-88301-01-4

I.S.B.N.: 978-84-9749-772-5 (electrónico) 


\section{INDICE}

I. INTRODUCCION

Alfredo Rodríguez López-Vázquez. ............................................... 7

II. RUPTURA Y NOVACION EN EL TEATRO VANGUARDISTA

DE RAMON GOMEZ DE LA SERNA (1909-1912).

Fidel López Criado

III. LA INFILTRACION DEL CUBISMO EN EL TEATRO JOVEN DE RAMON GOMEZ DE LA SERNA.

Alfredo Martínez Expósito

IV. LUGAR Y METAFORA: PERSPECTIVA DE METROPOLIS DESDE RAMON GOMEZ DE LA SERNA.

José Enrique Serrano Asenjo

V. LOS FRUTOS DE LA VANGUARDIA HISTORICA.

José Luis Bernal.

VI. PRESAGIOS DE TORMENTA: LA REVISTA

ATLANTICO (1929-1933)

José Carlos Mainer.

VII. ANTONIO MARTINEZ SARRION EN LA CRISIS DE LA VANGUARDIA: TEATRO DE OPERACIONES Y PAUTAS PARA CONJURADOS.

Francisco J. Díaz de Castro y Almudena del Olmo Iturriarte. 
La idea de este volumen, su razón de ser textual, surge del consenso fraguado en torno al ciclo de conferencias, "El nuevo siglo: el hombre y el arte en las vanguardias", celebrado en la Univesidad de A Coruña en octubre de 1994, donde algunos de los trabajos aquí recogidos (Bernal, Mainer, Díaz de Castro) no sólo ven la luz por primera vez, sino que sirven igualmente para alumbrar la urgente e imperiosa necesidad de revisar y ahondar críticamente la significación y trascendencia literaria de las vanguardias (las de aquel ayer histórico de principios de siglo y todas las que, desde entonces, se vislumbran con cada nuevo amanecer de la creatividad humana). Consecuentemente, los trabajos recogidos en esta edición dirigen su atención hacia unas parcelas de estudio que, ensombrecidas por el desconocimiento y la desatención crítica, han permanecido largo tiempo como el lado oculto de nuestras letras. No obstante, gracias al inestimable apoyo de tan notables estudiosos como los que aquí nos ofrecen generosamente el esfuerzo de su labor investigadora, hoy es posible hacer llegar el eco de unas Voces de Vanguardia que, en su conjunto, han contribuido decididamente a esa corriente de "novación" ético-estética de nuestras letras que, a su vez, hace posible el desarrollo cultural, social y político de nuestros pueblos. En este sentido, espero que este volumen sirva para estimular y potenciar un diálogo crítico cuya importancia y relevancia histórico-literaria parece verse reflejada, con particular contundencia y nitidez, por el creciente número de congresos y publicaciones que han surgido estos últimos años en torno a la producción literaria de las vanguardias españolas.

Fidel López Criado 


\section{La infiltración del cubismo en el teatro joven de Gómez de la Serna ${ }^{111}$}

Alfredo Martínez Expósito

DOI: https://doi.org/10.17979/spudc.9788497497725.057

(c) (i) (2)(2)

El teatro de Gómez de la Serna, que siempre había sido considerado como obra primeriza, extravagante y "prehistórica", alejada del resto de su ingente producción, ha empezado últimamente a ser comprendido como exponente preclaro de una transición histórica (Soldevila). Los quince dramas que entre 1909 y 1912 dio Ramón a la imprenta no comparten una misma estética sino que son muestra de la diversidad de soluciones y tentativas que Ramón va ensayando. De una calificación global de "teatro modernista" hemos pasado a una articulación entre tendencia modernista y tendencia vanguardista; obra clave, a nuestro entender, en esa tensión entre modernismo y vanguardia que estudian Rubio Jiménez y otros. Desde los primeros trabajos dedicados al tema siempre se ha dedicado mayor atención a la tendencia innovadora, vanguardista, debido quizá a lo premonitorio de su práctica. En este trabajo daremos cuenta de la filiación cubista de esa vanguardia juvenil de Ramón, y propondremos un paradigma cubista literario de ámbito paneuropeo.

111 Quiero agradecer a la Fundación Principado de Asturias la financiación concedida para realizar este trabajo, y a Ignacio Jiménez sus valiosas sugerencias. $A M E$. 
La historia del teatro ramoniano empieza a ser conocida gracias a trabajos aparecidos durante la última década, entre los que recordaremos las lúcidas reflexiones de García Pintado y López Criado, y los volúmenes monográficos de Palenque, Muñoz-Alonso y Martínez Expósito. Gracias a su recuperación crítica se ha comenzado a reinterpretar esa primera época ramoniana, anarquista y revolucionaria, cuyas máximas aportaciones, además del ya conocido El concepto de la nueva literatura, son El libro mudo (rescatado por Zlotescu) y la producción teatral y pantomímica. Palabras clave de ese período: rebeldía, anarquía, crisis personal, soledad, anhelo de algo nuevo. Y París: viajes de motivaciones y contenidos aún escasamente conocidos, con una componente política que se va haciendo evidente (Soldevila), pero que traerán, eso sí, el contacto con la vanguardia de la mano del cubismo (recuérdese El cubismo y todos los ismos, de 1921).

Ramón sonríe en 1909 a las proclamas futuristas, pero su teatro de ese año y del siguiente sigue girando sobre rescoldos tardo-simbolistas. Sólo en la eclosión productiva de 1911 (año en que aparecen en Prometeo siete de sus dramas) se perciben ya ciertos elementos netamente vanguardistas, que sin embargo tienen poco de común con el teatro sintético futurista; son rasgos (fragmentarismo, collage, pluriperspectivismo) de procedencia cubista, o que al menos presentan un "aire de familia" muy próximo a lo cubista. Lo cual no quiere decir, naturalmente, que el teatro ramoniano pueda ser adscrito en bloque a la denominada "literatura cubista".

Es ya lugar común no adscribir a Gómez de la Serna a ninguna generación o movimiento concreto; su figura y su obra parecen flotar en un éter omnipresente, participando de todos los hallazgos, vislumbrando todos los desarrollos, siempre en movimiento. De ahí la aparición de las ideas de Ramonismo o de generación unipersonal, fomentadas sin duda por el propio Ramón en un deseo singularizador. Pero por otra parte no es infrecuente oír hablar de cubismo y de estética cubista a propósito de la literatura ramoniana. Por lo general, se subraya el hecho de que Ramón mantuvo un estrecho contacto con el movimiento parisino ya desde su primer viaje en 1911 y se recuerda una cierta producción temprana de inequívoca filiación novista: la aparición en Prometeo de nombres representativos del nuevo arte, la traducción y comentario del Manifiesto Futurista, ciertas ideas contenidas en El concepto de la nueva literatura (de la Concha), su concepción del relato, la invención de la greguería, Ismos y su vinculación a la pintura nueva. El interés de Ramón por el cubismo, en fin, es evidente en toda su etapa juvenil. Su amistad con los promotores del cubismo está bien documentada: colabora con Apollinaire (firma incluso un prólogo para $I l$ y $a$ ), con Jean Cassou, 
escribe sobre Picasso, sigue las exposiciones del grupo. También es conocida su polémica con Huidobro, con el telón de fondo de la parte más hispana del cubismo, que es el creacionismo.

Técnicamente El teatro en soledad supone la más osada propuesta vanguardista de toda la dramaturgia ramoniana. ${ }^{112}$ Pero en casi todos sus dramas hay elementos novistas; habrá que recordar los retratos de los personajes de La casa nueva y de las piezas de marginados sociales próximas a la composición en collage; la creciente tendencia a la superposición de planos diferentes de realidad (Tránsito) y a la proliferación del pluriperspectivismo, traducción del facetismo cubista (El drama del palacio deshabitado); el ensayo de escenografía tardo-cubista de Los medios seres. Sin olvidar sus escritos sobre la pintura cubista (Ismos, por ejemplo), sobre sus artistas más relevantes (Retratos), y sus elogios al sentido cerebral de la mirada, y no nos quedará más remedio que reconocer que el arte cubista ejerce un notable magnetismo en el joven Gómez de la Serna.

Sin embargo el nombre de Gómez de la Serna no aparece en los estudios sobre el arte o la literatura cubista. ${ }^{113}$ Hay varias razones que contribuyen a explicar esa carencia. En primer lugar, no es el cubismo de Ramón una teoría plena, consciente y bien articulada, sino más bien una coincidencia de intenciones en su rechazo de los modelos simbolistas con el rechazo que promueve el grupo de Apollinaire. Puestos a comparar el cubismo ecléctico y un tanto accidental de Ramón con el más elaborado y consciente de Max Jacob o Gertrude Stein, no cabe duda de que se justifica la mayor atención que los estudiosos del cubismo prestan a éstos últimos. Por otra parte, ese deseo singularizador de Ramón ha producido desde siempre una extrañeza entre la crítica que se ha traducido en un no saber qué hacer con su figura; mientras que el cubismo de Apollinaire y de Réverdy, o el de Vallejo y Huidobro, o el de Picasso y Braque entran en paradigmas más o menos claros, en grupos o en facciones con cierta cohesión, la figura errante de Ramón hace del suyo un cubismo extravagante y, a la postre, insignificante para los historiadores del movimiento. En tercer lugar no debe olvidarse que el cubismo tal como ha llegado a nosotros es el resultado de un número de invenciones y de acuerdos

112 Wilma Newberry (1969), García de la Concha (1977), Yviricu (1977:79ss), MartínezCollado (1988:23), Muñoz-Alonso (1993:108ss), Martínez Expósito (1994).

113 Sobre literatura cubista: Lemaître (1941); Torre (1974); Carmody, Cubist Poetry, 1964; Guiney, Cubisme et littérature, 1972. Sobre cubismo en general: Cooper, The Cubist Epoch, 1971; Daix, Cubists and Cubism, 1982; Fry, Cubism, 1966; Golding, Cubism. A History and an Analysis, 1959; Roskill, The Interpretation of Cubism, 1985. 
entre sus inventores. En esa "política cultural" no ha tenido suerte Ramón, ni tampoco ningún otro literato español candidato a cubista, como Valle, Azorín, Jarnés o Espina; y ello debido, quizás, a la nula atención prestada al mundo hispano por los artífices de la historiografía cubista, desde Gleizes y Metzinger hasta Roskill.

No es por ahora nuestro deseo reescribir la historia del cubismo para dar cabida a nombres de nuestro entorno idiomático, pero sí será necesario para comprender el cubismo ramoniano repasar las condiciones en las que podemos hablar de un cubismo literario. El cubismo es uno de los más tempranos movimientos de la vanguardia histórica; tanto, que al principio no se distingue bien de los otros movimientos que empiezan a abundar. Todos comparten el optimismo cosmopolita y progresista que la nueva tecnología proporciona. Todos giran hacia París, la recién remodelada ciudad que ofrece un escenario vivo donde representar un nuevo arte que es vida (Shattuck). Todos rechazan con virulencia la idea del pasado, más que el pasado en sí; lo viejo es lo anquilosado, lo inerte, el encasillamiento academicista, mientras que lo nuevo es lo que vibra lleno de virtualidades, lleno de libertad para todas las mezclas y todos los incestos. Todos, pues, recurren a una idea sintetizadora del arte donde la vieja teoría platónica de las correspondencias, con Baudelaire y Mallarmé, desempeña un papel central.

El cubismo nace como técnica pictórica de la mano de Picasso y de Braque, que en seguida empiezan a ser imitados por Gleizes, Metzinger, Laurencin, y seguidos por Gris, Delaunay y otros. El grupo que nace alrededor del BateauLavoir incluye a artistas plásticos, a poetas y a escritores de diverso talante que comienzan a escribir y a divagar sobre la nueva manera artística. También participan marchantes y galeristas que contribuyen a su difusión. El grupo, liderado por Apollinaire hasta su muerte en 1918, produce fundamentalmente obra plástica, obra poética y obra ensayística; es lo que conocemos como escuela cubista francesa. Entre sus infinitas variaciones y desarrollos se incluyen el cubismo órfico de Delaunay, el cubismo dinámico de Marcel Duchamp, el neoplasticismo de Mondrian, el suprematismo de Malevich, el constructivismo de Tatlin, el purismo de Ozenfant y Le Corbusier y muchos otros. Existe además una escultura cubista cuya importancia, en las obras de Archipenko o Lipchitz, no se pone en duda; existe la arquitectura de Le Corbousier y de la escuela de Praga; y experiencias musicales, como las de Stravinsky o Satie; y cuadros cinematográficos, como el célebre Ballet Mécanique (1923) de Léger; y una poesía y un teatro abiertamente cubistas, o que al menos como tal fueron recibidos en su día. ${ }^{114}$

114 Margolius, Cubism in Architecture and the Applied Arts, 1979; Krauss, Passages in Modern Sculpture, 1977; Lawder, The Cubist Cinema, 1975; Glover, The Cubist Theatre, 1983. 
Existe una concepción del cubismo como escuela exclusivamente pictórica, que niega la posibilidad de aplicar el término "cubismo" a otras prácticas artísticas, o que concede sólo el uso metafórico del término a muy contados textos poéticos del entorno de Apollinaire. Tal concepción parece basarse en un criterio estético muy reductor, preocupado más por la ortodoxia terminológica que por el rigor estético e incluso histórico: el grupo cubista de París no fue, de hecho, un grupo de pintores sino de artistas. El espíritu de la época, el esprit nouveau, favorece la comunión de las artes y la disolución de sus diferencias sobre el mantenimiento de lo específicamente técnico y "académico". Recuérdese, sin ir más lejos, el parentesco entre pintura y poesía del que habla Jakobson en su "Futurisme" de 1919.

Con el precedente iconoclasta de Alfred Jarry, Apollinaire escribe en 1903 una farragosa obra fauvista, Les Mamelles de Tirésias, que Lemaître considera como obra basal de la literatura cubista, sobre todo por su uso continuo de la yuxtaposición. También cubistas son considerados los cuentos de L'Hérésiarque et cie por su composición fragmentaria y deslabazada; el criterio de fragmentarismo se convierte desde entonces en estandarte cubista. Más claramente cubistas parecen, sin embargo, los poemas de Alcools (1913) y la serie de Caligrammes que empieza en 1914. Criterios muy parecidos han sido esgrimidos al establecer como cubistas La guitarre endormie (1919) de Réverdy, Le cornet à dés (1917) de Max Jacob, Prikaz (1919) de André Salmon, Le cap de bonne espérance (1919) de Jean Cocteau y otros del mismo grupo. Estos y otros nombres como Pierre Albert-Birot o Nicolás Beauduin forman el grupo poético cubista, caracterizado según Torre por sus juegos de descomposición y recomposición, por su visión simultaneísta, por el predominio de lo intelectual sobre lo sensorial y de la invención sobre la creación, por la eliminación de lo anecdótico, por el fragmentarismo, por el menosprecio del sentimentalismo y por un humor ilusionado y jovial. Un ejemplo sería el siguiente poemilla de Alcools, fechado en septiembre de 1911, donde las fórmulas paratácticas comienzan a ganar terreno, la puntuación desaparece (como ya hiciera Mallarmé), y una cierta geometrización temática parece abrirse camino:

J'écoute les bruits de la ville

Et prisonnier sans horizon

Je ne vois rien qu'un ciel hostile

Et les murs nus de ma prison

Le jour s'en va voici que brûle

Une lampe dans la prison

Nous sommes seuls dans ma cellule

Belle clarté Chère raison 
El siguiente poema en prosa de Max Jacob procede de Cornet à dés, que apareció en 1917 con un aguafuerte del autor firmado por Picasso; obsérvese la constante contradicción de fragmentos yuxtapuestos:

ENCORE LE ROMAN FEUILLETON.- Robert s'appelait plutôt Hippolyte. Il eût été habillé à la dernière mode, s'il y avait eu une dernière mode, mais il n'y a pas de dernière mode; alors, il était habillé comme tout le monde, c'est-à-dire mal... Robert s'installa à table et mangea comme il n'avait pas mangé depuis longtemps, c'est dire qu'il mangeait peu, car il mangeait toujours beaucoup... S'il eût eu quelque tâche, il n'eût pas su s'en tirer, aussi n'en prenait-il-pas. Robert ne faisait rien, ce qui vaut mieux que de faire mal, et ceci ne l'empêchait pas de mal faire...

Casos asombrosamente similares encontramos en lengua inglesa. El vorticismo de Ezra Pound ha sido calificado por Shattuck como versión británica del cubismo. Los experimentos de Duncan Grant y Vanessa Bell están íntimamente relacionados con la búsqueda de la abstracción y el desarrollo de la teoría de las correspondencias. Gertrude Stein practica un cubismo consciente y deliberado de indudable raigambre pictórica pero de innegable sensibilidad literaria. Convivió con los artistas del grupo de París y escribió sobre ellos páginas memorables, como el famosísimo retrato de Picasso, repetitivo y musical como una letanía, e inteligente como el mejor cuadro cubista:

One whom some were certainly following was one who was completely charming. One whom some were certainly following was one who was charming. One whom some were following was one who was completely charming. One whom some were following was one who was certainly completely charming. Etc.

En lengua española hay que llamar la atención sobre la aparición del creacionismo de Huidobro y su carga teórica. Sabido es que su convivencia con Apollinaire, Reverdy y los otros cubistas entre 1916 y 1918 marcó definitivamente su idea del arte, y que la etiqueta creacionista no deja de ser la versión hispana del cubismo. De hecho Huidobro se convierte a partir de la publicación en 1925 de sus Manifestes en figura central del cubismo francés, en un momento en el que ya el surrealismo de Breton ha asumido el liderazgo artístico (cf. Verani). 
Las características centrales del creacionismo, tal como las resume Huidobro en sus manifiestos "Non serviam" y "El creacionismo", son una versión ligerísimamente modificada de lo que hasta ahora hemos visto como cubista: 1, Arte como creación pura, principio antimimético: "No he de ser tu esclavo, madre Natura. Seré tu amo"; 2, Inversiones: humanizar lo inanimado, hacer abstracto lo concreto y concreto lo abstracto. Subvertir los valores usuales para favorecer la creación de objetos nuevos; 3 , El poema es exclusivamente un producto de la imaginación. Todo lo anecdótico y lo descriptivo carece de interés; 4, Enfasis en los efectos tipográficos y en la apariencia plástica del poema impreso; 5, Tendencia a la supresión de enlaces lógicos, a la desarticulación de la lógica lingüística, a la simultaneidad espacio-temporal, a la yuxtaposición de imágenes distantes e insólitas.

En ocasiones se ha hablado de rasgos cubistas en obras que no responden a una estética conscientemente cubista: ocasionales descripciones de personajes o paisajes, narraciones abruptamente fragmentadas (Salinas, Víspera del gozo), etc. Otras veces se ha hablado de composiciones marcadamente cubistas y construidas según esa estética: Soldevila considera Tirano Banderas novela cubista, Conte habla de Paula y Paulita, de Jarnés, como novela cubista.

Respecto a Gómez de la Serna se venía rondando el tema desde muy atrás, pero fue Wilma Newberry en 1969 quien comenzó a hablar de una poética cubista en El teatro en soledad, de 1912, cuestión que sería de nuevo abordada por Yviricu y, más en general, por García de la Concha. Los rasgos cubistas de los que hablan son: el principio antimimético y creacionista; el realismo fundamental como opuesto al principio de abstracción, al que nunca llega el cubismo; la poca importancia de la verosimilitud y del argumento; la fragmentación; la composición en forma de conglomerados de elementos atomizados o collage; la superpocisión de planos diferentes de realidad; el pluriperspectivismo; el intelectualismo. Es decir, la misma receta que encontramos en todos los anteriores, desde el grupo de París hasta el creacionismo de Huidobro.

La necesaria definición de una estética interdisciplinar, con cultivadores en diferentes países y en el período inestable de entreguerras no es sencilla. Intentaremos dibujar sus líneas de fuerza sobre cuatro aspectos esenciales: la cuestión de la mirada, la concepción de la realidad, el experimentalismo y la deshumanización.

Primero. La mirada cubista es sin duda el marbete que mejor caracteriza la nueva estética. Por mirada habría que entender mejor el ojo que al mirar no sólo capta, como el ojo hegeliano, sino que capta e interpreta y robustece 
aquello que mira; son los ojos de Picasso, que cantó Alberti como "ojos animales", "ojos cataclismo, / temblor, / terremoto, / maremoto, / abismo, / flor". Es una poderosa mirada en libertad que no cabe ya en las normas tradicionales de representación, válidas desde el Renacimiento. La dislocación de las formas conocidas, la proliferación de otras formas e imágenes insólitas, incluso ilógicas o absurdas, procede de la conjunción de tres principios que sustituyen al perspectivismo clásico: la fragmentación de lo percibido y de la percepción misma, el principio de simultaneidad y la técnica pluriperspectivista.

La modernidad entera, y el cubismo en particular, ama lo fragmentario, lo discontinuo, lo abrupto; se busca con ello el sorprender, el épater, mantener al espectador en un estado perpetuo de agitación y de alarma perceptiva. Y más allá de esa intención pragmática, un nuevo modo de composición basado en yuxtaposiciones insólitas que aseguren la ostranenie de la que a propósito del cubismo ruso habla Sklovski. El collage picassiano es tan fragmentario como el poema de Alberti que antes citamos o como la composición misma del libro donde se empezó a inventar el cubismo, las Méditations esthétiques de Apollinaire (Bozal 1994), o como la aún poco estudiada prosa "ultraísta" de Buñuel (Fuentes 1986).

El simultaneísmo es otro de los lemas de la modernidad. Es claro ya en la mayoría de los simbolistas y en los impresionistas, pero se fortalece definitivamente en las vanguardias con futuristas cono Soffici y Severini y con cubistas como Delaunay. En pintura se emparenta con la técnica pluriperspectivista, que rompe con el punto de fuga único al favorecer perspectivas locales que en ocasiones se superponen; el ejemplo clásico sigue siendo Les demoiselles d'Avignon (1907), donde se localizan puntos focales diferentes para cada figura del cuadro, como si el observador se hubiera situado en puntos diferentes para enfocar cada una.

La mirada cubista encuentra su expresión paradigmática en los ojos de Picasso y en los ojos de Ramón ${ }^{115}$, sobre todo en los ojos conceptuales del Ramón de las greguerías, que constituyen quizá la mejor aportación española al cubismo literario. Con estos ejemplos en mente podremos entender el carácter metonímico de la manera cubista de percibir el mundo. Quizá fue

115 Maestro indiscutible de todos los vanguardistas españoles en este sentido. "Sutil pupila la de Ramón. Ir tras ella es resignarse al zurrón de Lázaro, porque sólo deja migajas de las cosas. Arte que agudizó muchos ojos, que pudo agudizar otros muchos escondidos bajo espesas gafas doctorales. Ramón, monstruo de mil pupilas, ha abierto un ancho polígono donde se aprende a abatir falsas siluetas" (Jarnés, 70-71). 
Jakobson el primero en advertir una oposición entre el surrealismo, de resabio metaforizante, y el cubismo, de neta tendencia metonímica. Sin duda sería interesante profundizar en los procedimientos metonímicos de textos cubistas, a semejanza de lo que Nicolás propone sobre la greguería.

Interesa, por último, al tratar de la mirada cubista, notar que lo que el ojo cubista ve, a fin de cuentas, es la realidad en sus formas fenoménicas. Nunca llega el cubismo, por definición histórica, al mentalismo antimimético, que equivaldría a renunciar definitivamente a la percepción física, sensorial. Por muy grande que sea el conceptismo cubista (y lo es) no transpasa la frontera del concepto de representación. Dicho de otra manera, no se llega a la abstracción de Kandinsky ni al absurdo de Ionesco. Eso sí, el foco de interés se ha desplazado con tanta fuerza del objeto a la mirada, de lo representado a la representación, que Apollinaire llega a sostener: "La verosimilitud ya no tiene ninguna importancia, puesto que el artista lo sacrifica todo a las verdades, a las necesidades de una naturaleza superior que él supone sin descubrirla. El tema ya no importa nada o apenas nada" (Apollinaire 1913).

Segundo. La concepción de la realidad. El carácter realista del cubismo fue una de las primeras constataciones de sus propios teóricos y practicantes. El nuevo modo de captación de lo real pretendía no encerrarse en la perspectiva única tradicional, sino acceder al objeto desde la totalidad de sus percepciones. La teorización cubista, ya desde Gleizes y Metzinger, ofrece así una apariencia de fenomenología artística de enorme influencia en toda la vanguardia. Como hemos visto, lo que suele ocurrir al intentar atrapar la verdad esencial y polimorfa es que el artista proyecta sobre la realidad toda su particular forma de enfocar las cosas, toda la arbitrariedad de su mirada. Y esto se hace, en los casos más puros de Picasso y Braque, con una intención eminentemente experimental de lograr un modelo alternativo de aprehensión de lo real. Pero la propia realidad es objeto también de relativizaciones.

Todavía está de moda en los principios de la vanguardia la teoría simbolista, de estirpe idealista y platónica en su origen, de la existencia de dos realidades, una formal y aprehensible mediante los sentidos y otra ideal y accesible sólo al entendimiento. El cubismo, siguiendo el patrón idealista, otorga preponderancia a la realidad intelectual, que además es capaz de enaltecer y elevar ontológicamente a la realidad inmediata. Es el no pinto lo que veo sino lo que entiendo picassiano.

Obviamente, la concepción bergsoniana de la realidad como fluido en constante cambio, de imposible percepción por su misma inaprehensibilidad, está presente en el cubismo y en toda la época vanguardista. De ahí el reavivamiento de posiciones sobre la inefabilidad del arte y sobre la función 
cuasi-sacerdotal del artista, de estirpe romántica. O, en otra versión de lo mismo, y en consonancia con Nietzsche y Dewey, el tópico de que sólo existe la realidad ideal, siendo lo material puro espejismo amorfo a la espera de nuestra conformación mental. Línea que explica afirmaciones como que la torre Eiffel no existía hasta que la vio Delaunay, y más aún, la súbita existencia que cobran los objetos de Stein y Gómez de la Serna ${ }^{116}$.

Pero la postura más significativa resulta ser la vía creacionista: el arte, más que reproducir la realidad, la crea. Este principio, claramente expresado por Huidobro, por Réverdy, por Gómez de la Serna, aparece prácticamente en todos los cubistas e implica una posición inédita del arte respecto a su materia prima, la realidad. La posición ancilar y secundaria del arte en la tradición platónica cede ahora ante una ecuación de términos iguales, cuando no en una directa inversión de valores. En los casos más extremos se postula la existencia única del arte; más frecuente resulta, sin embargo, la afirmación más comedida (aunque igualmente revolucionaria) de la obra de arte como entidad autónoma, autosuficiente, independiente del mundo real, que se verá favorecida por las nuevas teorías formalistas y proto-semiológicas que nacen de la mano del nuevo arte.

Tercero. La vocación experimental es otro aspecto general de la vanguardia que encuentra en el cubismo la correspondiente respuesta. No conviene reducir el concepto de arte experimental al muy estrecho de arte fallido o preparatorio o arte de ensayo; Picasso es rotundo: yo no busco, encuentro. La esencia del experimentalismo, tan vilipendiado por los degustadores de un arte más reglamentado, no es otra que la de proponer nuevos procedimientos para lograr los mismos propósitos de siempre; no estamos hablando de un paradigma estético diferente, sino de modificaciones o innovaciones meramente formales. Siendo el cubismo un movimiento esencialmente formal no es extraño que se propongan constantemente formas nuevas de lograr lo de siempre, que era en pintura la representación del objeto, o en novela la narración de una historia. La ruptura de los moldes clásicos que a finales del XIX tiene lugar en todas las artes obliga a los vanguardismos del XX a plantearse la actividad artística como una investigación formal. Pruebas manidas de ello son los juegos tipográficos que abundan en la obra de Joyce, Woolf, Apollinaire, y que apuntan claramente a la idea de un arte reflexivo, vuelto sobre sus propios códigos y preocupado por la posibilidad de hacer del propio lenguaje un nuevo topos artístico.

116 "El Madrid de Gómez de la Serna: hasta él no existe" es el significativo título de un artículo de Díaz-Cañabate, Indice de artes y letras, 76, p.7, 1955 
Cuarto. "Deshumanización". Este término, que en el mundo hispano ya no se puede escribir sin comillas, procede en realidad de Blast, manifiesto cubista (vorticista) inglés redactado bajo el liderazgo de Wyndham Lewis en 1914, que a su vez coincide asombrosamente con Una bofetada al Gusto Público, manifiesto cubo-futurista ruso de 1912. Para una mentalidad tan intelectualizada y cerebral como la cubista nada podía causar más enojo que las efusiones sentimentales que Ortega describe en su ensayo. Al cubismo, simplemente, no le interesan las pasiones humanas; en todo caso se admiten para animar, humanizar, los objetos inanimados, las cosas tan queridas a Ramón y a Stein, el primero con sus rastros y sus baúles, la segunda con sus Tender Buttons (1914), retratos de objetos como éste:

\begin{abstract}
A RED HAT.- A dark grey, a very dark grey, a quite dark grey is monstrous ordinarily, it is so monstrous because there is no red in it. If red is in everything it is not necessary. Is that not an argument for any use of it and even so is there any place that is better, is there any place that has so much stretched out.
\end{abstract}

Una lectura reposada del desprecio cubista por el público (piénsese en el futurista placer de ser silbado, la bofetada al gusto público, el deleite de ser ignorado por la masa anodina de Ramón en el Epílogo a Los Sonámbulos y en el Prólogo a La Utopía (1911), la literatura que abomina de la masa voraz de la que habla Tzara) conduce con seguridad a ese elitismo intelectual que subyace a la mayoría de los cubistas. Conscientes de estar realizando un arte no masivo (a pesar de los escándalos, organizados, de los pintores cubistas de París) frente al éxito del romanticismo tardío, de la gran novela realista, del folletín, del folklore, los cubistas se hacen fuertes en un arte de gran dificultad que selecciona con rigor a su público. Las huellas del lector que encontramos en la pintura cubista o en los poemas cubistas revelan el tipo de deshumanización al que nos referimos.

Creemos importante, al movernos en literaturas cubistas, tener presentes estas cuatro nociones o principios, sin olvidar la existencia de otros elementos que, si no definidores del cubismo, sí son frecuentes en sus producciones: la trivialidad de sus temas, la mezcla de ironía y severidad, el trasfondo metafísico y aun espiritualista, la nueva importancia del yo entendido como pluralidad de niveles de consciencia...

Los dramas ramonianos son un depósito de textos de variada condición. En ellos encontramos acción netamente teatral, pero también numerosas aco- 
taciones liminares, prólogos, descripciones, manifiestos literarios, etc. La obra se convierte en una ocasión ceremonial que atrae intereses adyacentes, ideas anexas, comentarios. En La casa nueva, por ejemplo, encontramos unas insólitas descripciones de los personajes, que parecen más dirigidas al lector que a un virtual director de escena. Un ejemplo sería la dedicatoria a Ricardo Baeza, multiplicado, "dispersado en distintos Ricardos Baezas urbanos y sigilosos y viajeros", pero es llamativo el sentido pictórico de que dota a los personajes del drama, enfocando siempre sus ojos:

\begin{abstract}
AMANDA.- Ojos empañados, con titubeos, que miran suspensivos, colgada a ellos la mirada, elevadas las cejas como presenciando una gran presencia. La boca hace, en sus comisuras, un gesto arrobado y su sombra fuerza en un signo la boca y la hace decir su deseo y su promesa. Todo su rostro está lleno de timidez, esa timidez carillena, que imita a la luna. Los arcos de su nariz se curvan con sombras, vivaces, con ese gesto inquieto en que juega toda la sensibilidad temblorosa en el vahído que dan los olores acres...
\end{abstract}

O la mirada: “¡Ojos con mirada más que con pupila!... En su mirada está todo el ardor y toda la puntuación de la figura, que si no sería átona". ¿Cómo sustraerse a la evocación del Portrait de Fernande (1909) de Picasso, a la devoción del cubismo por el retrato?

Mucho de collage, o sea, de composición fragmentada, encontramos en las obras corales de la marginación, sobre todo en Los unánimes (1911). El collage utilizado en novela o teatro para el desarrollo de un argumento implica un grado de ruptura en el relato; más aún, de incongruencia. El efecto sorpresivo del collage consiste en romper toda isotopía, léase coherencia. Poggi ha estudiado el origen cubo-futurista del collage pictórico y Rosalind Krauss ha ofrecido una interpretación del procedimiento como recurso irónico. Los personajes de Los unánimes son todos el mismo y todos diferentes:

Todos ellos resultan hechos retazo a retazo, en cambios de color que no se funden, sino que se reúnen con las ensambladoras líneas de plomo de los vitrales. Todo después de ellos parece que adquiere la dura y recalcitrante visualidad de alta vidriera.

Un grupo de mendigos en la calle, a la espera de que una puerta que permanece cerrada se abra. La puerta al final se abre, en efecto; y todos, "paso a 
paso, silenciosos", entran por ella; pero nos quedamos sin saber adónde conduce ni para qué entran. El collage de personajes guarda un sentido hermético: hablan entre sí en términos sólo vagamente comprensibles. Queja, angustia, solidaridad... pero poco más. El dictamen de Gardiol ("The conclusion is not clear and the work is ambiguous", 1974:38) es el mejor diagnóstico posible de una poética cubista. Collage y hermetismo, no lo olvidemos, son ingredientes favoritos del cubismo.

Al final de Los unánimes encontramos uno de esos extraordinarios escritos teóricos de Ramón que por encontrarse unidos a los dramas nunca han recibido la misma detenida lectura de otras piezas. Comienza el escrito sobre tema social (colofón del drama) y termina en pleno alarido vanguardista, reivindicando el azar como procedimiento artístico. El tema, en principio, no puede ser menos vanguardista: relata cómo cierto día se encontró por la calle con la escena de patética mendicidad que el drama acaba de escenificar. Resuenan ciertos tristes arlequines de la época azul de Picasso, o, en fin, toda la literatura de denuncia social del momento. Este motivo sirve de arranque a una divagación en la que se exploran algunos de sus aspectos, especialmente su vertiente ético-social y sus posibilidades estéticas. Ahora bien, ya nada más comenzar encontramos este inequívoco posicionamiento novista:

En un momento teatral en que todo es atavismo en la escena y en que se habla como de una novedad del teatro poético - ese teatro de torpeza, arrebatado y disipador- he escrito este drama sediciente, con las apostasías que comprometen al autor, pero que no comprometen al suceso dramático, abandonado a sus incongruencias y al encresparse de sus palabras. / Es un barrunto que en una vida llena de incertidumbre, es por lo menos el preliminar a la vida verdadera.

Es decir, es consciente de estar intentando apartarse de un modelo artísticamente coherente pero falseado a la vez, y a la busca de algo más incongruente pero a la vez más verdadero. Quizá no es eso lo que logra en las excesivamente farragosas páginas anteriores a 1913, pero sí es, a lo que parece, lo que persigue; y, desde luego, en perfecta consonancia con los principios apollinairianos.

Pero hay algo más. La mímesis cubista, según vimos, no se basa en la imitación formal sino en una reproducción conceptual mediatizada por el ojo y la memoria del artista. Los cubistas no pintan sobre modelos, sino sobre 
recuerdos; uno de los párrafos más repetidos de la crítica cubista es éste de Apollinaire:

Lo que diferencia al cubismo de la antigua pintura, es que no es un arte de imitación, sino un arte de concepción que tiende a elevarse hasta la creación. ${ }^{117}$

Ramón nos explica en este Estrago Final cómo surgió la composición de Los unánimes, y nos está dando una clave claramente cubista: no refleja en la obra lo que vio un día por la calle, sino una modulación mental que construye sobre el recuerdo de algo que vio una vez y ya no volvió a encontrar jamás, y que somete a una conceptualización arquetípica. Veamos este fragmento:

Un día vi el escenario de este drama en un barrio extremo. Y me ha resultado incomprensible no volverlo a encontrar, habiendo ido varias veces en su busca ... Allí vi unos miserables extraños, los miserables de excepción, no los miserables asiduos y cuotidianos de la cristiandad, los miserables que, como no sucede con el cabecilla revolucionario siquiera, dan la sensación sin menoscabo, sin angostura y sin lirismo de la impavidez y la disidencia. Siempre he sentido una rara atención por esos miserables que andan por el sitio abrupto y vacío de las calles ... No son símbolos aproximados del grande hombre usual, del Dante, de Cervantes, de Kant. De ningún modo. Son hombres más incidentales, menos contenidos y menos incontinentes, más imposibles, que no han retenido la autoridad pública con la flaqueza de los grandes hombres usuales.

No estamos ante un caso más de costumbrismo naturalista, ni mucho menos ante un ejercicio simbolista. Lo que Ramón plantea es la construcción

117 Página 30 de la traducción española. Esto es lo que se lee en el prólogo al ramoniano Ismos: "Así como lo que diferencia al cubismo de la antigua pintura es que no es un acto de imitación, sino de concepción, que puede elevarse hasta la creación, la nueva literatura de Apollinaire se diferenciaba de la otra por las mismas razones". Bozal (1994:102) ha tratado de explicar el significado de ese arte de concepto sin lograr una clave satisfactoria, pero considera que estas palabras no fueron ocurrencia ocasional. Propone finalmente interpretarlas como la pérdida de la percepción empírica como criterio privilegiado de la representación. 
de una abstracción, de un arquetipo -esos miserables que no son símbolos pero que comparten unánimemente su miseria- a partir de rasgos reconocibles, tópicos, de cualquier miserable cotidiano. Años después Ramón será capaz de decir todo esto más elegantemente, declarando, por ejemplo, que más que las cosas en sí le interesa lo que las cosas llevan dentro de sí, lo que gritan desde su interior, y será capaz de reducir todos los maniquíes a ese concreto maniquí arquetípico que contiene a los demás. En Los unánimes opera un parecido proceso de abstracción para, inmediatamente, multiplicar a ese miserable de excepción en una docena de miserables que, cual nuevo coro trágico, entona su letanía colectiva.

Hacia el final del Estrago aparecen, de manera un tanto incongruente, una apología del azar y una confusión de voces. El tema del azar aparece unido al del miserable arquetípico de la obra, y termina en boca del propio Ramón, que lo asume como propio:

¡El azar!... ¡Hallarlo todo en él sin malicias técnicas, sin a prioris, sin truc! ¡Por eso todas mis palabras y mis pensamientos están sometidos a la desorientación del azar y en él los oriento! ¿Pero quién oye desde el azar? Nadie.

Otro epílogo interesante es el de Los sonámbulos (1911), que habría que relacionar con los desdobles del yo típicos de toda la vanguardia y que ya Apollinaire usa poéticamente en Alcools. El epílogo está firmado por el seudónimo Tristán, que Ramón viene usando desde 1909 y que aparece en $E l$ libro mudo (1910) como auténtico alter ego o, como quiere Zlotescu, homogénimo; es una técnica la del desdoble que incide en esa obsesión por el yo de la que también ha hablado Hoddie a propósito de Morbideces. Se lee en Los sonámbulos:

El teatro de Gómez de la Serna es un teatro de colocación... Va a dar, como toda la obra de este autor, obra de exclusión y de perdición, al lienzo más religioso del espacio, al más revelador, al más opulento: al Oriente... Ese es su gran sacrilegio.

Es precisa una gran cautela ante estos escritos ramonianos, pues a menudo explican más sus intenciones que los logros que pretenden explicar. En este caso, sin embargo, hay algunas cosas claras que han despejado dudas serias acerca de la primera época del escritor y de su idea del teatro. Por 
ejemplo, tiene clara la irrepresentabilidad de sus dramas, más por motivos estéticos que técnicos:

Por esto mismo, el Teatro de Gómez de la Serna es irrepresentable. Todos los teatros miran a Occidente, pues es un defecto de unilateralismo el de los espíritus, defecto de occidentación.

En 1912 publica Gómez de la Serna El teatro en soledad. Para su estudio es necesario partir de dos premisas: esta obra se había ido gestando por lo menos desde 1909 con el comienzo del experimentalismo dramático que iría abriendo caminos expresivos hacia un tipo de teatro fundamentalmente diferente al canon modernista (frente a la opinión de Camón Aznar); y su composición no hubiera sido posible antes del viaje de Ramón a París (Soldevila, Newberry). En otro lugar hemos explicado la circunstancia bloomiana que concurre en el joven escritor de 24 años, incomprendido pero libre ya de las angustias imitativas, que contribuyen a explicar la dedicatoria:

A Eugenio Noel, porque sí, y porque comprenderá este drama por toda la soledad vibrante que vivió en aquel sótano con ratas y filtraciones en que fui el primero en conocerle hace años, una magnífica soledad ...

Tras la Depuración Preliminar, verdadero manifiesto que por ahora pasaremos por alto, comienza la obra propiamente dicha. En el Acto I acaba de concluir en el teatro una representación, el público se ha ido y sólo quedan los actores, tramoyistas y demás personal. En una escena de realismo vulgar y anodino comentan la obra recién representada, sucesión pintoresca de diálogos en torno a la farándula. Finalmente se despiden y se van; en la acotación que explica esto se produce una de las transiciones más seductoras y plásticas del todo el teatro de Ramón:

... Se escucha el ruido de una llave al cerrar y después unos pasos, el son de un llavero y un portazo lejano... Larga pausa, en que la escena, después de haber olvidado la última palabra, se queda medrosa y ardiente de un ardor negro con inquietudes ultravioletas, toda llena de éxodo, de resolución, y de puro no esperar nada reincidentede todas las esperanzas ... Se siente que tiene que caer una verdad inaplazable de esa bóveda accidentada y empozada de telares ... (Acto I). 
Entonces, en ese espacio vacío y negro, que en cierto momento se equipara al vientre materno por su capacidad de germinación, surgen unos personajes nuevos, diferentes, extraños y de apariencia incorpórea, que parecen surgir de las entrañas mismas del teatro. Son personajes innominados, reconocibles sólo "por lo que más brilla en ellos o lo que más negrea, y sólo eso se basta de carácter y de decisión". Son los Protagonistas, porque los otros, los de carne y hueso, sólo habían sido seres accidentales en la vida del teatro. Perspectiva teatral doble que de manera inusitada y sorprendente plantea el teatro dentro del teatro pero no como una convención o un truco, sino como efecto real y objetivo del teatro mismo.

Hablan entre sí en un lenguaje diferente, entre mistérico y hermético, del que se deduce la diferencia de su condición. Comentan el horror y el asco de esos seres diurnos y mezquinos que estropean las cosas del teatro con sus pequeñeces y sus obcecaciones. Se espantan, en coral unanimidad, de ese público aplaudidor y llano. Pero rápidamente entran en su tema: son personajes y deben representar su drama, titulado Conclusión, "en que añadirán un esfuerzo y una incontinencia más al deseo de su gran obra cuotidiana, llena de vida privada y desarropada".

El Acto II de El teatro en soledad es el primero de Conclusión. La escena, que antes estaba poblada por los decorados realistas del drama diurno, aparece ahora "cubierta de una cortina corrida, de terciopelo negro, que cae en grandes pliegues absolutos": estamos ante el escenario mudo y neutro del teatro ramoniano en su máxima expresión; ya no es preciso localizar la acción en boscajes abstractos ni en nocturnos salones venecianos: ahora se ha llegado a la neutralidad y a la mudez absoluta. En el centro, un cadáver en su catafalco y una mujer que lo llora. Súbitamente deja de llorar, su rostro se crispa y huye de la escena pidiendo socorro. Al rato reaparece junto a un hombre, "el descarnado", con quien desarrolla un diálogo comenzado fuera.

El primer acto de Conclusión desarrolla la relación entre la viuda, "la de la frente lunar", y el descarnado. Nada sabemos de ninguno de los dos. El descarnado es un ser extraño, que enseguida logra sacar a la de la frente lunar de su mundo prototípico y cuadriculado para poco a poco introducirla en un concepto diferente de la existencia:

El descarnado (con una flema recia y conmovedora).- Eres la mujer de todos los dramas... La pobre mujer de todos ellos, llenos de dolores falsos que te han ocultado al dolor... Sólo has llorado siempre deteniéndote en tu drama, inutilizándote en él con toda tu carne sin iniciar... Hay que mascar y asimilar todo lo trá- 
gico... Llorar no, eso inferna y hace demasiado exterior y demasiado definitivo lo que ha de internársenos y ha de hacernos pasajeros ... (Acto II).

Nueva perspectiva doble: la mujer pertenece a un drama falso y tópico, que inutiliza las pasiones, mientras que el hombre representa una realidad diferente, un drama diferente que pronto la mujer ansía conocer. El descarnado le presenta a su gente en un acto de aspecto iniciático:

El descarnado (presentádoles con un gesto sin brazos).- Mi gente. (Y acercándose a ella y enlazándola por el cuello en un gesto avezado y soberano). Mi hembra... Como os he dicho, ha resistido el empuje y es virgen y siente vuestro nidero de cosas en el pecho... (Acto II).

Traban una extraña amistad en una serie de conversaciones a través de las cuales se parece ir diseñando un ideario de tipo moral, pasional, que afecta incluso a la propia concepción estética del drama y de la obra teatral; se mueven sólo para procurarse placer y bienestar unos a otros, y sólo las grandes pasiones y los grandes sufrimientos parecen tener una justificación en ese mundo alternativo.

El segundo acto de Conclusión, tercero y último de El teatro en soledad, se abre con un largo parlamento entre dos mujeres, la de la frente lunar y la descotada, acerca del mundo de la mujer, que nos recuerda las largas disquisiciones de El laberinto (1910). Y se cierra la obra cuando aparece de nuevo el descarnado y se exacerba el drama que mantiene con la de la frente lunar. Se ven obligados a profundizar en su relación de una manera nueva que obligue a las mayores sinceridades: el drama de ser continuamente nuevos el uno para el otro:

El descarnado.- Mujer mía, después de habernos dicho esto, sé fuerte y sé nueva y seamos adúlteros con nosotros mismos... Nuestro drama es un drama de que hartarse y al que no rechazar... Vivamos del él ... (Acto III).

Conclusión y El teatro en soledad terminan con el comienzo de un nuevo drama, que exalta la noche y el pecho: "Cae el telón sin gran prisa, 
cuando se ven ya su descote y sus brazos, fascinadora de materialidad y de desvergüenza".

La complejidad de la obra, como se deduce de este resumen argumental, es extraordinaria. A las dificultades técnicas se une la escritura críptica que ha desarrollado Ramón, y que si no consigue transmitir con claridad las ideas que sustentan esa filosofía de la vida y del arte, sí logra transmitir un suficiente grado de dificultad como para que cualquier lectura reduccionista perciba la radical necesidad de novedad vital que plantea.

La técnica de ir encajando unos dramas en otros, desde el más visible (Conclusión en El teatro en soledad) hasta los más sutiles (los múltiples dramas que cada personaje dice representar) es quizá el ingrediente más revulsivo de la obra. Es en todo caso el aspecto que más llama la atención, desde el momento en que la ideología que se pudiera extraer de la obra queda lo suficientemente oscurecida como para resultar incluso incoherente. Todos los ingredientes de vitalismo, sensualismo, apasionamiento, iconoclastia, rebelión, etc., están al servicio de una idea global de alejamiento del patrón establecido; lo que en esta obra encontramos, desde el comienzo al final, es una continua huida y superación en términos vitalistas de todo aquello que se va imponiendo como fijo: los comentarios de los actores tras la obra superan a la obra, las pasioncillas de los actores entre sí superan a esos comentarios, la aparición de los nuevos personajes supera a la realidad de los actores, la introducción de la nueva obra supera la neutralidad de los personajes, la propuesta vital del descarnado supera la supuesta vida aburrida de la de la frente lunar, el descubrimiento mutuo de la capacidad de novedad que ambos se deparan supera a su primera relación. Estamos ante una huida hacia adelante, ante la superación continua y la necesidad de cambio como principios constructivos de la obra. Al final, la distancia que separa los diálogos de los tramoyistas de la propuesta final entre el descarnado y la de la frente lunar es más cualitativa que cuantitativa: se pierde la noción de distancia, e incluso la de diferencia parece limitada.

El principio cubista de romper la perspectiva única, ya sea multiplicándola, ya negándola y haciéndola desaparecer, encuentra en El teatro en soledad una solución repetida varias veces: duplicarla. Cuando comienza la obra se supone que la sala está vacía, pues los espectadores de la función de la noche ya se han marchado. Se ignora deliberada y explícitamente la existencia del nuevo público, el que asiste a El teatro en soledad, con lo cual se obtiene una primera duplicación: la sala acoge a dos públicos, el público ficticio y ausente de la obra finalizada y el público real pero ignorado de El teatro en soledad. Inmediatamente se produce un caso de auténtica polifonía 
escénica con varios núcleos de actores reclamando simultáneamente la atención del público: los tramoyistas desde fuera del escenario, electricistas entre bastidores, uno que sale por la concha del apuntador, los grupos de actores que hablan de cosas diferentes, el director que los reúne, etc. El efecto conseguido es enormemente realista, ya que se tiene la impresión de que realmente estamos asistiendo al batiburrillo de después de la función, pero examinada con un criterio formal toda la situación está compuesta al modo de un collage, a base de elementos heterogéneos y yuxtapuestos. La complicación de este pluriperspectivismo alcanza mayores cotas con la ruptura de la separación entre la sala y el escenario, que es una de las convenciones más universales del arte escénico: explícitamente se hace mención a que el conserje y el acomodador vienen de cerrar las puertas de los palcos y anfiteatros, y por lo tanto vienen por el patio de butacas.

El procedimiento del "teatro dentro del teatro" contribuye a poner en crisis las convenciones teatrales, cuestionando el estatuto semiótico de la obra en la que se manifiesta pues al igual que la mise en abîme y todas las ficciones de segundo grado, contribuye a quebrar el funcionamiento del texto que lo contiene. En El teatro en soledad se rompe no sólo la división del local en sala y escena mediante la utilización de todo el local como escena, sino también la unidad dramática de la obra, al presentar una obra dentro de otra obra, $\mathrm{y}$, como hemos visto, una proliferación de microdramas dentro del collage dramático del primer acto, que en cierta medida reaparece al final del tercer acto con la propuesta de un nuevo drama que ya no cabe en El teatro en soledad. Lo que de esta manera se consigue es la neutralización de la distancia que el teatro impone entre el público y la obra, introduciendo al público en el propio lugar de la obra, inaugurando una línea de experimentación teatral vanguardista que alcanzará su punto máximo en las técnicas del psicodrama y del happening.

Igual que los cubistas, Ramón juega en este drama con la superposición de distintas facetas, tanto de la realidad como de la ficción, para al final hacer un collage con todas ellas. Todas las discusiones del primer acto giran entorno a la realidad convencional del teatro, planteando en el fondo el problema de la interpretación dramática, la concretización en la escena de un drama ideal escrito en el papel, semejante a la traducción en sonidos que el músico hace de los signos gráficos de la partitura. Pero, como dice Yviricu,

lo paradójico de este ensayo es que mientras se categoriza lo real de irrealidad teatral por todos sus fallos y limitaciones, lo ideal (los personajes y su drama indefinido), es lo que resulta real al final de la obra (1977:96). 
La compleja mezcla de realidad e irrealidad, de proximidad y de fantasía, responde en última instancia a un collage que refleja la realidad teatral, partiendo de un momento de análisis (des-construyendo todos los elementos de las convenciones teatrales) y culminando con una reconstrucción de la esencia final del drama:

El descarnado.- Mujer mía, después de habernos dicho esto, sé fuerte y sé nueva y seamos adúlteros con nosotros mismos... Nuestro drama es un drama de que hartarse y al que no rechazar... Vivamos de él... Siéntete grande en medio de él, necesítale como paisaje sustituto en medio de tu placer y de tu dolor... Rotos todos los motivos de todos los dramas, llegó el drama absoluto, franco de fuerza y de extensión... Seremos más virtuosos cuanto más vivamos de este drama y más lo justifiquemos... Es el drama sin remordimientos de conciencia... El drama que no está en el conflicto de la hipocresía con la inmoralidad, sino en no poder sobrepasar la inmoralidad... El drama, en fin, nada más que "el drama", sin ningún argumento pequeño ni grande... Sin ningún tercero entre nosotros, y sin ningún tercer pensamiento, sólo hecho para nosotros dos, que los hemos asumido con nobleza... (Acto III).

Por supuesto que hay otros muchos elementos no cubistas en esta obra: el tema y el tono son serios, éticos, trascendentales, alejados del juego cubista.

Años después vuelve Ramón al teatro con Los medios seres, en plena efervescencia vanguardista. A la altura de 1929, en el momento del surrealismo, el cubismo es ya cosa del pasado. La obra de Ramón, pensada más para satisfacer el morbo de las audiencias que como obra de vanguardia, sorprende por lo gastado de sus fórmulas. Efectivamente, los trajes y decorados participan de un cierto cubismo descafeinado, con un parentesco menor con los ideados para la escena cubista rusa (Diaghilev, Mayakovski).

Conclusión.- El cubismo puede ser interpretado como un paradigma estético que produce diferentes textos artísticos en las primeras décadas del siglo. Como tal paradigma ofrece variaciones y particularidades en los diferentes países y en los diferentes códigos artísticos en los que se encuentra presente. Los rasgos que definen al cubismo respecto a otras propuestas vanguardistas son: una manera esencialmente conceptista de mirar la realidad, 
que conjuga la percepción física con la elaboración mental; una idea de la realidad heredada del idealismo, que admite diferentes formulaciones respetuosas con la idea básica de que la realidad aprehensible por los sentidos no es la única; el principio irrenunciable del texto como laboratorio semiótico, o sea, la obra como experimento y juego; el absoluto desinterés por lo sentimental, lo melodramático y lo argumental.

El joven Gómez de la Serna fue desde sus inicios una atenta antena a todo tipo de novedad, sea cual fuere su procedencia. Gracias a su especial disposición y a sus viajes a París, la estética cubista se infiltró pronto en sus escritos; así, el teatro que escribe entre 1909 y 1912 ejemplifica perfectamente la transición del modernismo a la vanguardia, transición de la que no está ausente la influencia cubista. El cubismo no es en el joven Ramón una estética predominante, y sería vano buscar un principio poético claramente cubista en ninguna de sus obras anteriores a 1913. Pero sí es posible localizar elementos de raigambre cubista en sus textos dramáticos. En las obras que hemos seleccionado para este escrutinio hemos localizado composición en collage, experimentación perspectivística, fragmentación de todo tipo de unidades, desdoblamiento del yo, tendencia al retratismo, y adscripciones explícitas a los principios de realidad superior y de la mirada conformadora de lo real.

Estos elementos emparentan a Gómez de la Serna con un grupo internacional al que pertenecen también Apollinaire, Max Jacob, Gertrude Stein, Huidobro, Pound, Mayakovsky y otros, para quienes el paradigma cubista fue un momento importante en su práctica literaria, y que, si bien no quedaron anclados en él, sí le debe muchos de sus logros estéticos.

\section{Referencias}

Apollinaire, Guillaume, (1913), Alcools. Cito por Oeuvres Poétiques, Gallimard, 1956.

Apollinaire, Guillaume, (1913), Méditations esthétiques. Les peintres cubistes, Paris, Figuière. Traducido como Meditaciones estéticas. Los pintores cubistas, Madrid, Visor, 1994.

Bozal, Valeriano, (1994), "Apollinaire y el cubismo", en su edición de Apollinaire, Meditaciones estéticas: los pintores cubistas, Madrid, Visor, pp. 89-111.

Camón Aznar, José, (1972), Ramón Gómez de la Serna en sus obras, Madrid, Espasa-Calpe. 
Conte, Rafael, (1994), edición de Viviana y Merlín, de Jarnés, Madrid, Cátedra.

Fuentes, Víctor, (1986), "La prosa poética de Buñuel: del dadaísmo ultraísta al surrealismo", en Burgos, ed., Prosa hispánica de vanguardia, Madrid, Orígenes, pp. 209-218.

García de la Concha, Víctor, (1977), "La generación unipersonal de Gómez de la Serna", Cuadernos de Investigación Filológica, III, pp. 63-86.

García Pintado, Angel, (1988), "El eslabón perdido (... y hallado fuera del templo)", El público. Cuadernos, 33, pp. 4-8.

Gardiol, Rita M., (1974), Ramón Gómez de la Serna, New York, Twayne.

Gleizes \& Metzinger, (1912), Du cubisme, Paris, Figuière.

Hoddie, James, (1979), "El programa solipsista de Ramón Gómez de la Serna", Revista de Literatura, XLI (82), pp. 131-148.

Jakobson, Roman, (1919), "Futurism", Iskusstvo, 7; cito por Pomorska \& Rudy, eds., Language in Literature, Cambridge Harvard U.P, 1987, pp. 28-33.

Jakobson, Roman, (1956), "Two Aspects of Language and Two Types of Aphasic Disturbances", Fundamentals of Language, The Hague.

Jarnés, Benjamín, (1927), Ejercicios, Madrid.

Krauss, Rosalind, (1980), "Re-presenting Picasso", Art in America, 68/10, pp. 90-96.

Lemaître, George, (1941), From Cubism to Surrealism in French Literature, New York, Russell \& Russell.

López Criado, Fidel, (1994), "El teatro de lo imposible y la imposibilidad del teatro innovador de Gómez de la Serna", en Paz Gago, ed., Semiótica y Modernidad, vol.II, La Coruña, pp. 197-210.

Martínez Expósito, Alfredo, (1994), La poética de lo nuevo en el teatro de Gómez de la Serna, Oviedo, Universidad.

Muñoz-Alonso López, Agustín, (1993), Ramón y el teatro: la obra dramática de Ramón Gómez de la Serna, Ciudad Real, Universidad.

Newberry, Wilma, (1969), "Cubism and Pre-Pirandellianism in Gómez de la Serna", Comparative Literature, XXI, pp. 47-62.

Nicolás, César, (1988), Ramón y la greguería: morfología de un género nuevo, Cáceres, Universidad de Extremadura.

Palenque, Marta, (1992), El teatro de Gómez de la Serna. Estética de una crisis, Sevilla, Alfar. 
Poggi, C., (1993), In Defiance of Painting: Cubism, Futurism and the Invention of Collage.

Roskill, Mark, (1985), The Interpretation of Cubism, Philadelphia, Art Alliance Press.

Rubio Jiménez, Jesús, (1993), El teatro poético en España: del modernismo a las vanguardias, Murcia, Universidad.

Shattuck, Roger, (1968), The Banquet Years. The Origins of the Avant Garde in France, 1885 to World War I (Alfred Jarry, Henry Rousseau, Erik Satie, Guillaume Apollinaire), New York, Vintage.

Soldevila, Ignacio, (1986), "Valle-Inclán y las vanguardias literarias: la composición de Tirano Banderas como novela cubista", Simposio Internacional Valle-Inclán y su tiempo, Madrid, Círculo de Bellas Artes.

Soldevila, Ignacio, (1988), "Para la recuperación de una prehistoria embarazosa. (Una etapa marxista de Gómez de la Serna)", en Dennis, ed., Studies on Ramón Gómez de la Serna, Ottawa, Dovehouse Editions, pp. 2343.

Stein, Gertrude, (1912), "Picasso", en Camera Work. Escrito en 1909.

Torre, Guillermo de, (1974), Historia de las literaturas europeas de vanguardia, 3 vols., Madrid, Guadarrama.

Verani, Hugo, (1986), Las vanguardias literarias en Hispanoamérica. (Manifiestos, proclamas y otros escritos), Roma, Bulzoni.

Yviricu, J., (1977), Del vanguardismo en el teatro de Ramón Gómez de la Serna, Ann Arbor, Michigan.

Zlotescu, Ioana, (1987), "El libro mudo, luz en los orígenes de Ramón Gómez de la Serna", en su edición de El libro mudo. (Secretos), de Gómez de la Serna, Madrid y México, Fondo de Cultura Económica, pp. 13-67. 